\title{
MOBILE PHONE: AN INSTRUMENT OF DISSEMINATING REQUISITE AGRICULTURAL INFORMATION FOR THE AGRICULTURAL DEVELOPMENT OF BANGLADESH:
}

\author{
A CASE STUDY
}

\author{
Md. Mahedi Hasan ${ }^{1}$ \\ ${ }^{1}$ Assistant Professor, Department of Business Administration, Prime University, Mirpur-1, Dhaka, Bangladesh
}

\begin{abstract}
Bangladesh is densely an over populated country where a large number of people (more than 60 percent) are still living their livelihood directly or indirectly through the agro based jobs. The environment is very much favorable for agriculture. The contribution of agricultural sector to GDP is $20.60 \%$ In this regard, if the initiatives are been taken to provide the right farmers with the right information by the right way at the right time within the least cost, the success will be definite. Decision making is a very crucial part in every activity to be performed in an excellent manner. Any system applied for getting information and knowledge for making decisions in any industry should deliver accurate, complete, concise information in time or on time. The information provided by the system must be in user-friendly form, easy to access, cost-effective and well protected from unauthorized accesses. And to ensure all these there is no alternative other than telecommunication and networking technologies. Different collaboration and communication tools are available to share information throughout the world to ensure improved decision making. And those tools are also playing an important role to disseminate agricultural information. Mobile phone is one of the most popular electronic media among the natives of this country for news and information. Mobile phones significantly reduce communication and information costs for the rural poor in developing countries. This not only provides new opportunities for rural farmers to obtain access to information on agricultural technologies, but also to use ICTs (Information and communication technologies) in agricultural extension systems. Since 2007, there has been a proliferation of mobile phone based applications and services in the agricultural sector, providing information on market prices, weather, transport and agricultural techniques via voice, short message service (SMS) and internet.
\end{abstract}

Therefore, this paper attempts to analyze the contribution of mobile phones on the dissemination of agricultural information for the farmers for their agricultural enrichment with emphasis on analyzing quantitative data gathered in a survey using a structured questionnaire that was generated on the basis of my theoretical study. Findings indicate a positive curve towards the dependency on and contribution of mobile phones.

Keywords: Agricultural Information, Mobile Phones in Bangladesh, Agricultural Information Service (AIS), Technology Adoption, E-agriculture.

\section{INTRODUCTION}

Bangladesh being an agricultural country, the importance of the agriculture sector has long been recognized by the Government of Bangladesh (GoB). To make the agricultural sector as an engine for economic development the adoption of technology is must. Broadly speaking, technology is the "relationship between inputs and outputs" (Foster and Rosenzweig 2010), or the set of hardware (physical) and software (techniques) tools that allow for a different mapping of inputs to outputs. In the context of agriculture, hardware refers to improved cultivars (seeds), fertilizers and pesticides, whereas software refers to practices such as intercropping, mulching, and integrated pest management. We can define adoption of technology as the "use of new tools or techniques that relate inputs to outputs and the allocation of inputs" (Foster and Rosenzweig 2010).
Different Government Organizations (GOs) and NonGovernment Organizations (NGOs) are trying with diverse initiatives for strengthening the agriculture sector of Bangladesh. Though various efforts of improvement are in there, but the agriculture sector is facing a range of challenges for its development like over population, political instability, climate change, loss of agricultural land, infertile land, use of excessive pesticides, lack of inputs, improper irrigation etc. For providing agricultural information to the farmers GOs and NGOs has taken some time befitting initiatives. The Government of Bangladesh has established Agricultural Information Service (AIS) through which training guides, newsletters, radio \& TV programs, films etc. are arranged for disseminating information. In 2010, AIS has developed SMS based information service with the help of a mobile operator 'Banglalink' and UNDP in the country. Since October 2008, an e-agriculture initiative 
known as "e-Krishok" has been using information and communication technologies to deliver information and advisory services to farmers in rural and remote locations at a lower cost. In 2009 ministry of agriculture in Bangladesh with support from UNDP Bangladesh has initiated Agriculture Information and Communication Centers (AICC) in 20 areas. And agricultural information service has piloted 10 farmers community based Call Centers in those twenty areas (ebangladeshexpo, 2013). Despite those initiatives, most of the farmers of Bangladesh are still in lack of information and modern agricultural knowledge. They need an easy access point to get and meet their information need. Information need has three basic elements: availability, access and utilization. But the GOs and NGOs initiatives are hard to reach and they lack ease of use by the farmers.

Under the above circumstances, this study has tried to measure the contribution of mobile phones in disseminating agricultural information in Bangladesh.

\section{LITERATURE REVIEW}

Information plays a vital role in agricultural development and production and their effective communication will help facilitate mutual understanding among farmers, agricultural scientist and extension workers (Agboola, 2000). According to Kaye (1995) good information improves decisionmaking, enhances efficiency and provides a competitive edge. Knowledge and information are basic ingredients for increased agricultural production and productivity. Information is a critical resource in the operation and management of the agricultural enterprise (Opara, 2008). Abbas et al. (2008) argued that lack of information adapted to local needs and lack of technical knowledge at farm level are the important factors responsible for this low yield. Information is therefore considered as one of the most important resources in agricultural and rural development that assists the farmers to take decisions and appropriate actions for further development related to farming (Harris et al., 2001; Morrow et al., 2002 and Stefano et al., 2005).

Mass media methods in agricultural information dissemination generally, are useful in reaching a wide audience at a very fast rate. They are useful as sources of agricultural information to farmers and as well constitute methods of notifying farmers of new developments and emergencies. They could equally be important in stimulating farmers' interest in new ideas and practices (Ani et al. 1997). Mobile phone can provide an illiterate person valuable instruction and education in agriculture, health population control, sanitation and other aspect of his daily life (Rahman, 1999). This paper tries to present the effect of agricultural information transmitted by the mobile phones of Bangladesh towards the development of the farmers of my native Upazilla Saghata of Gaibandha District of Rangpur Division of Bangladesh.

\section{CONCEPT OF AGRICULTURE AND E- AGRICULTURE}

Agriculture includes farming crops, animals, fishery and foresting contributions. Farming corps includes paddy, wheat, jute, vegetables, sugarcane, pulses etc; animal farming includes dairy, poultry, fishery, sericulture etc.

The main phases of the agriculture industry include crop cultivation, water management, fertilizer application, fertigation, pest management, harvesting, post-harvest handling, transport of food products, packaging, food preservation, food processing/value addition, quality management, food safety, food storage, and food marketing. All stakeholders of agriculture industry need information and knowledge about these phases to manage them efficiently.

E-Agriculture is an emerging field focusing on the enhancement of agricultural and rural development through improved information and communication processes. More specifically, e-Agriculture involves the conceptualization, design, development, evaluation and application of innovative ways to use information and communication technologies (IT) in the rural domain, with a primary focus on agriculture. And to convert agriculture into e-agriculture in a developing country like Bangladesh the mobile phone can play an important role. Because more than $80 \%$ people of Bangladesh are using mobile phone to communicate with others as well as more than 5000 million taka are transacted daily by the mobile user (According to Bangladesh Bank, the central bank of Bangladesh).

\section{FARMER'S INFORMATION NEEDS}

Farms In a country like Bangladesh are extremely small, cultivation is dependent on the uncertainties of variable rainfall, floods, natural disaster and political instability and average output is generally low. Addition of value in agriculture sector requires technological, institutional and price incentive changes designed to raise the productivity of the small farms (Todaro, 2000). Small farmers are entangled within a vicious cycle because of sharecropping, tenancy, money lending and other structural and financial relationships with owners and traders (Crow, 1999). The situation of the vulnerable farmers is exacerbated by the land erosion, drought, flood, deforestation and other natural calamities. These together with lack of access to finance reduce farmers' propensity to take risks. The bargaining power of farmers in the input market is not very strong with the result that farmers pay high prices for inputs thereby reducing their net earnings. Lack of bargaining power also impacts adversely on the prices farmers receive for their produce. Low net earnings in turn reduce the capacity and incentive to make productivity improving investments. The reason behind all of those is the unavailability of right information at right time at the right place. Propagation of relevant information to the farming communities can facilitate the effective adoption of agricultural inputs, decision making on markets and adoption of scientific 
methods. However, lack of sharing of information across the agricultural supply chain is a major concern in Bangladesh. Over the years it has been found that in Bangladesh there is a strong correlation between the use of ICT mostly the mobile phones and farmers' productivity. The use of mobile phones can also increase farmers' bargaining power.

By getting the access to information through mobile phones at any place at any time, small scale farmers are better able to compete with the larger operators. They can even develop knowledge regarding crop choices, develop products for the niche markets and even can market the products directly to the consumers. If they are been deprived to get the access to knowledge and communication capabilities the small farmers remain at the mercy of the global market forces.

\section{MOBILE PHONE OPERATORS IN BANGLADESH AND THE SERVICES PROVIDED BY THEM}

The information disseminated by mobile phones can be divided into several major areas, which is called as services of e- Agriculture (Panchatopa D. and Karmakar C. K. 2006). These are:
$\checkmark \quad$ Weather Information
$\checkmark \quad$ Production and Cultivation Techniques
$\checkmark \quad$ Diseases and Insect Information
$\checkmark \quad$ Plant Nutrients and Water Usage
$\checkmark$ Price Information
$\checkmark \quad$ Demands and Current Stock Information
$\checkmark \quad$ Educations and Health Information
$\checkmark$ Government and Non-government Facilities

To make this information available the leading mobile phone operators of Bangladesh like Grameen Phone, Banglalink established call centre, providing agriculture information through their large mobile network to all over the country for target people.

But still there are lots of challenges among those one of the primary challenges of disseminating requisite information to the farmers in Bangladesh is the absence or limited presence of expert consultation in rural vicinities.

Some other challenges like many other domains, agricultural knowledge becomes outdated quite quickly and it is often hard to regularly train extension agents working in the field with up-to-date information. Moreover, currently there is no specific mechanism in place to regularly train extension agents after a certain interval in a proper learning environment. In addition, in the field extension agents are not equipped with any sort of tool or materials that can be used to improve their service delivery.

Another major challenge is that the decision-makers have limited tools to collect real time information from the field when taking timely decisions. Extension agents in the field collect and prepare a massive amount of ground level data, such as crop statistics and visit log, which is vital for managers and decision makers in order to plan future activities. Currently data collection is done through a traditional paper-based system, and therefore aggregating all the data collected requires a big amount of staff time. Hence, when it comes to management level, which is far from the ground, it often takes more than fifteen days to elaborate data from the fields, and this means that decision makers have very little time to send out meaningful and effective instructions in emergency situations such as floods and other natural hazards.

To solve these three specific issue, mPower Social Enterprises Ltd of bangladesh has developed an integrated ICT approach which includes a big amount of mobile and web apps, multimedia content for mobile phones, and even community radio programs.

To solve the very first issue, the lack of extension agents, mPower has developed a community based, infomediary driven approach. In each of the farmer group, the community selects an 'ICT Leader', a member of their community who owns a Smartphone. These ICT leaders are trained by the project and they are provided with a mobile application named 'Farmer Query System'. Fig-1shows when farmers in the community face a particular agriculture challenge, through this app the ICT Leaders send the details of this problem to a call center where expert agriculturists respond to the query through a phone call, becoming a virtual extension agent. Moreover, female farmers are also more prone to get reliable and certified agricultural information as the person who is sending the query on her behalf is community member himself.

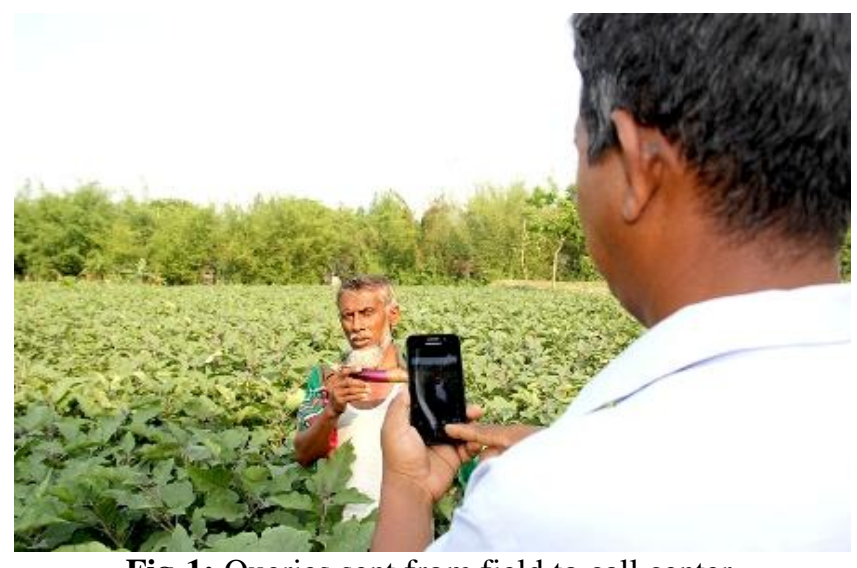

Fig-1: Queries sent from field to call center

Agriculture Knowledge Bank, an online repository of agricultural content which can also be accessed through mobile app, has been developed in collaboration with various government research institutes and extension department of Bangladesh in order to solve the challenge of updating the extension agent with most recent knowledge. Many research agencies in Bangladesh produce a lot of content which is stored in their own website. Existing rural telecenters, innovative farmers or extension agent who tries to use ICT or mobile web to extract information from web, often face a hard time because for a single piece of information they often have to roam through multiple 
government websites. Hence this knowledge portal, which is also linked with learning tools and powers the various diagnostic tool, aids extension agents to learn more about each of the topics with updated information ( shown in Fig2).

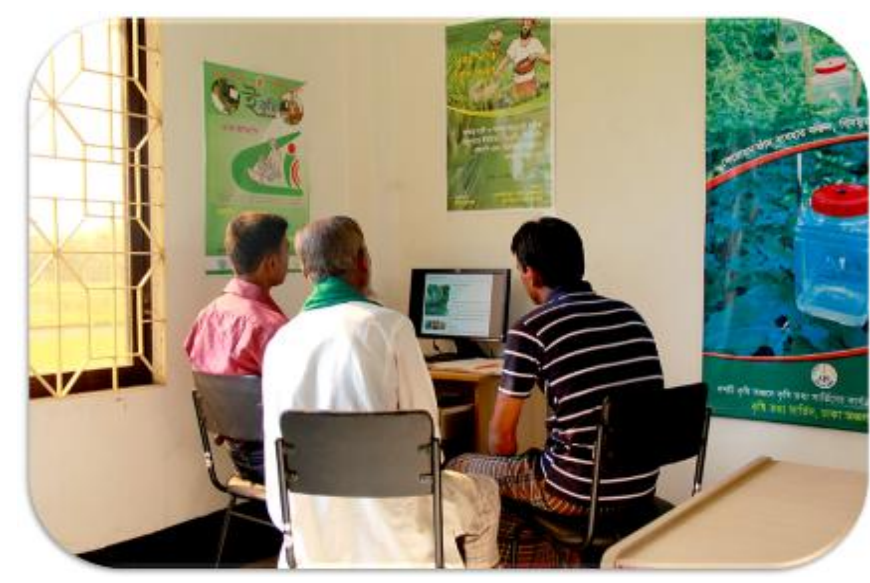

Fig-2: Telecenters using Agro Knowledge Bank

To automate the reporting and data collection process of extension department which is challenge three, mPower, in collaboration with extension department of Bangladesh, has developed three mobile applications which automate their scheduling process, statistics collection and problem tracking, with the positive result of eliminating a lot of paperwork. This data are being automatically aggregated in real time, and managers sitting remotely can see the view in a web dashboard and can give timely and meaningful forward instructions (shown in Fig-3).

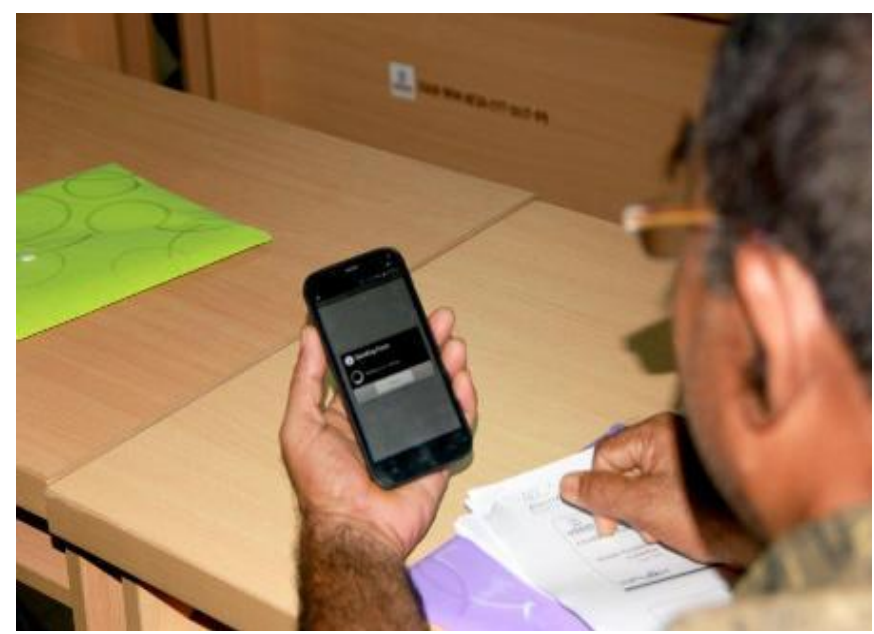

Fig-3: Extension Agent using reporting tool to submit statistics

Now I am trying to show the statistical position of mobile phone users as well as internet users in Bangladesh.

The total number of Mobile Phone subscribers has reached 115.627 million at the end of April 2014.
Table-1: Mobile Phone Subscribers

\begin{tabular}{|l|l|}
\hline Operators & $\begin{array}{l}\text { Subscribers (in } \\
\text { million) }\end{array}$ \\
\hline Grameen Phone Ltd. (GP) & 48.847 \\
\hline $\begin{array}{l}\text { Banglalink Digital Communications } \\
\text { Limited }\end{array}$ & 29.449 \\
\hline Robi Axiata Limited (Robi) & 24.062 \\
\hline Airtel Bangladesh Limited (Airtel) & 8.503 \\
\hline $\begin{array}{l}\text { Pacific Bangladesh Telecom Limited } \\
\text { (Citycell) }\end{array}$ & 1.425 \\
\hline Teletalk Bangladesh Ltd. (Teletalk) & 3.342 \\
\hline Total & $\mathbf{1 1 5 . 6 2 7}$ \\
\hline
\end{tabular}

*Subscribers in Millions

**The above subscribers' numbers are declared by the mobile operators.

Internet Subscribers in Bangladesh in February 2015 (According to BTRC)

The total number of Internet Subscribers has reached 43.419 million at the end of February, 2015.

Table-2: The Internet subscribers

\begin{tabular}{|l|l|}
\hline OPERATOR & SUBSCRIBER \\
\hline Mobile Internet & 41.959 \\
\hline WiMAX & 0.215 \\
\hline ISP + PSTN & 1.245 \\
\hline Total & $\mathbf{4 3 . 4 1 9}$ \\
\hline
\end{tabular}

* Subscribers in Million

**The above mentioned figure represents the number of Active subscribers only. A subscriber/ connection using the internet during the last Ninety (90) days is considered to be an Active subscriber.

From the above statistics we can say that mobile phone can be a major instrument of disseminating agricultural information to the farmers for the development of agricultural sector in Bangladesh.

\section{METHODOLOGY}

The two main categories of data are: primary data and secondary data. Primary data refers to the data that has been gathered specifically for the ongoing research while secondary data has been gathered previously on another circumstance. The article is been prepared by using both the primary data and secondary data. Secondary data are collected from secondary sources such as government publication, personal records, census and Primary data collected through observation, interview and/or questionnaires (Hair et al 2003). I also talked informally to extract the most possible data from the respondents. The gathered data has analyzed by simple tabular and graphical and percentage representation.

I have collected my questionnaire's answer only in Yes, No scale and some in Excellent, Good, Satisfactory, Fair and Poor scale. 


\section{OBJECTIVES}

The main focus of this research is to elaborate how the achievements of IT can be applied through mobile phones in Agriculture sector and its development.

The broad objectives of this study are -

- Identifying agricultural information needs of the rural Bangladeshi farmers: What are the problems faced by the rural Bangladeshi farmers with regard to production and marketing of agricultural commodities?

- To find out which mobile phone operators are preferred by the respondents.

- To determine what type of agricultural information the respondents get from the mobile operators.

- To identify the farmer's initiatives to apply knowledge in their agricultural process after getting information by mobile phone.

\section{FINDINGS AND ANALYSIS}

\subsection{Age of the Respondents}

The table represents the information of respondent's age where it is seen that majority number 20 (28.57\%) of respondent's age level is between (26-30) years followed by $22.86 \%(31-35)$ years, $21.43 \%(20-25)$ years and $17.14 \%$ (36-40) years. The least number is $10 \%$ whose age is above 40.

Table-3: Age of the Respondents

\begin{tabular}{|l|l|l|}
\hline Age (by year) & Respondents & Percentage \\
\hline $20-25$ & 15 & 21.43 \\
\hline $26-30$ & 20 & 28.57 \\
\hline $31-35$ & 16 & 22.86 \\
\hline $36-40$ & 12 & 17.14 \\
\hline $40+$ & 7 & 10 \\
\hline Total & 70 & 100 \\
\hline
\end{tabular}

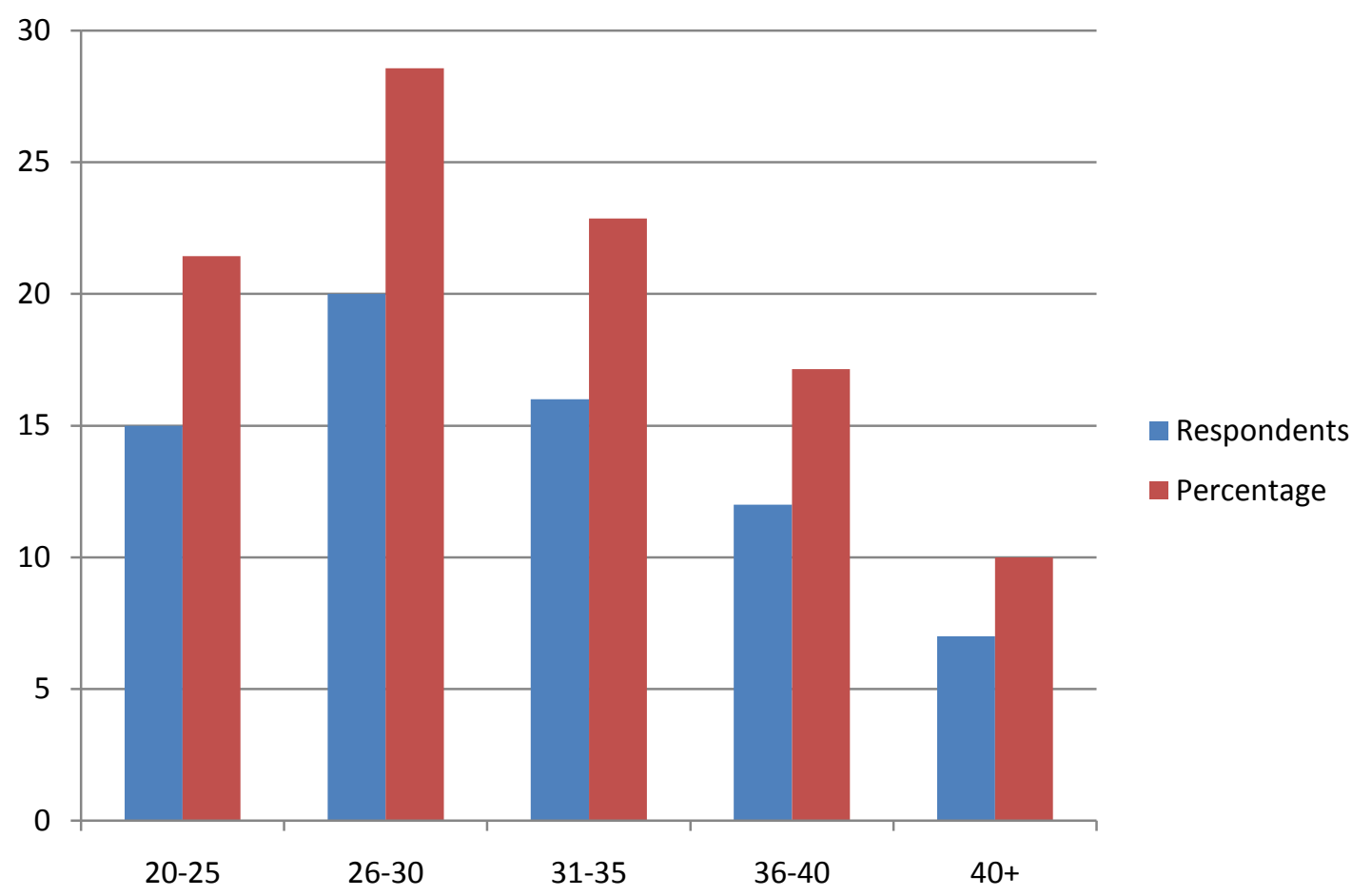

Chart-1: Age of the Respondents

\subsection{Educational Qualification:}

Education is the key to all success. An educated person is generally wide awake. And such person knows what is good for life and which is not propitious for life. Table- 4 narrates about the educational qualification of the respondents. As of the table it is observed that the largest proportion 18 $(25.71 \%)$ of the respondents have completed primary education where as $22.86 \%$ respondents have completed the higher secondary level education. Moreover only $11.43 \%$ respondents have finished diploma education and $5.71 \%$ respondents cannot read and write. Besides, no respondents have graduate.
Table-4: Respondents Educational Qualification

\begin{tabular}{|l|l|l|}
\hline Educational & Respondents & Percentage \\
\hline Signature literate & 10 & 14.29 \\
\hline Primary education & 18 & 25.71 \\
\hline Secondary School & 14 & 20.00 \\
\hline Higher Secondary & 16 & 22.86 \\
\hline Diploma education & 8 & 11.43 \\
\hline Graduate & 0 & 0.0 \\
\hline Illiterate & 4 & 5.71 \\
\hline Total & 70 & 100 \\
\hline
\end{tabular}




\subsection{Occupation}

In Table- 5 the occupation of the respondents has been expressed. It is noticed that the big number 38 (54.28\%) of respondents lead their live depending on the agriculture while the least portion $8(11.43 \%)$ of respondents depends on both agriculture and jobs. Besides, 34.29\% respondent's occupation is simultaneously agriculture and business.

Table-5: Occupation

\begin{tabular}{|l|l|l|}
\hline Name of the occupation & Respondents & Percentage \\
\hline Agriculture & 38 & 54.28 \\
\hline Agriculture and business & 24 & 34.29 \\
\hline Agriculture and jobs & 8 & 11.43 \\
\hline Total & 70 & 100 \\
\hline
\end{tabular}

\subsection{Frequency of Using Mobile Phone to Retrieve}

\section{Their Desired Information}

Now we are living in the digital age. We, from every areas just can't imagine our life without the make use of technology mostly the mobile phone. And farmers are not any exception.
And in the present situation it will be difficult to find those who do not use the mobile phone. Now a day, mobile phone has been the sources of entertainment and different news of both home and abroad that may cover social, cultural, political, educational, agricultural, economical, health, geographical, environmental, religious and others information. Table 6/ Chart-2 reveal the information regarding the frequency of using mobile phone by the respondents to get their desired information. It is observed from the table/bar graph that majority number $32(45.71 \%)$ of respondents use mobile phone irregularly where as $25.71 \%$ respondents use it every day. And $20(28.58 \%)$ respondents commented that they do not use it anytime.

Table-6: Frequency of using mobile phone

\begin{tabular}{|l|l|l|}
\hline Answer & Respondents & Percentage \\
\hline Every day & 18 & 25.71 \\
\hline Irregular & 32 & 45.71 \\
\hline Not applicable & 20 & 28.58 \\
\hline Total & 70 & 100.00 \\
\hline
\end{tabular}

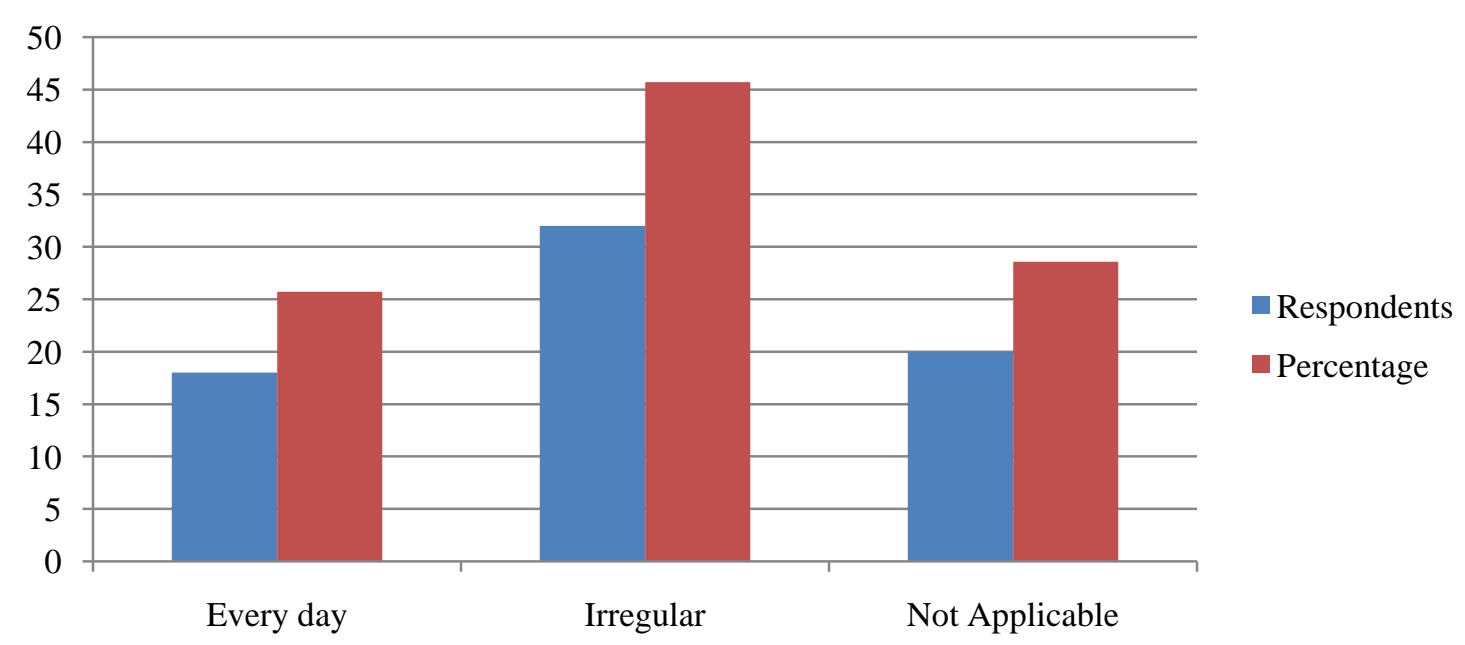

Chart-2: Frequency of using mobile phone

\subsection{Preferred Mobile Phone operators for}

\section{Agricultural Information}

Table-7 shows the preferred mobile phone operators to search out Agricultural Information. Majority number 32 $(45.72 \%)$ of respondents use Grameen phone to get agricultural information followed by 18 (25.71\%) Banglalink, Robi $12(17.14 \%)$, Teletalk 2 (2.86\%) and Citycell 6 (8.57\%).

Table-7: Preferred Mobile phone operators for Agricultural Program

\begin{tabular}{|c|c|c|}
\hline Preferred & TV|Respondent & Percentage \\
\hline Grameen phone & 32 & 45.72 \\
\hline Banglalink & 18 & 25.71 \\
\hline Robi & 12 & 17.14 \\
\hline
\end{tabular}

\begin{tabular}{|l|l|l|}
\hline Teletalk & 2 & 2.86 \\
\hline Citycell & 6 & 8.57 \\
\hline Airtel & 0 & 0.0 \\
\hline Total & 70 & 100.00 \\
\hline
\end{tabular}




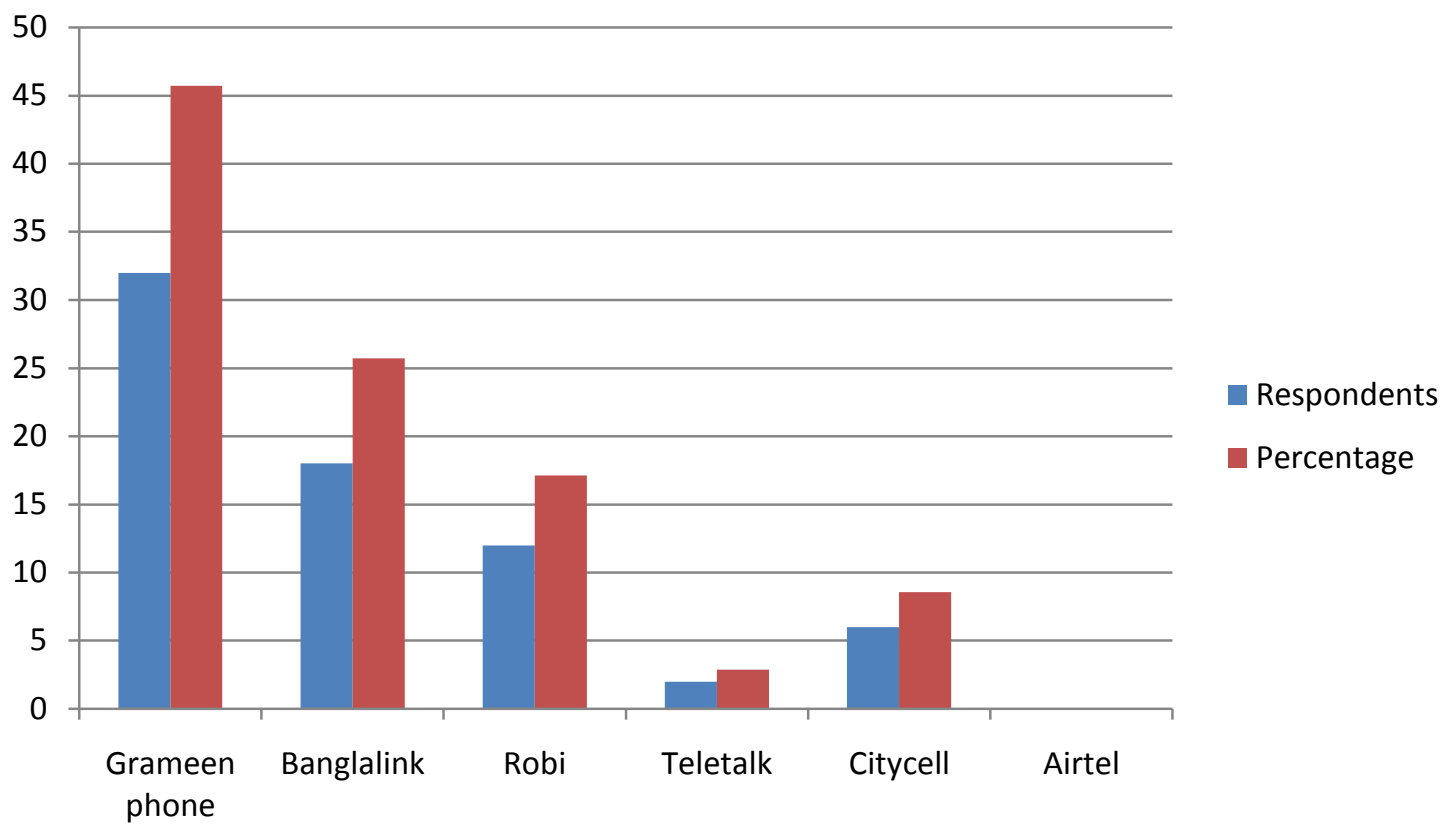

Chart-3: Preferred Mobile phone operators for Agricultural Program

\subsection{Types of Agricultural Information the \\ Respondents Get}

Table-8 demonstrates that majority number 50 (13.19\%) of respondents get the quality information regarding quality seeds while the information of fertilizer is got by 47 $(12.40 \%)$ respondents. Besides these, 43 (11.35\%), 40 (10.55\%), $37(9.76 \%)$ respondents collect the information on pest control information , Irrigation and Water management, and Seasonal fruits, vegetables information respectively. Moreover, information on poultry firm and fishing are got by $35(9.23 \%)$ respondents respectively. Furthermore, the least number $15(3.96 \%)$ of respondents have said that they get the information on soil testing and uncomplicated cultivation information respectively.

Table-8: Types of Agricultural Information the Respondents get from the Mobile phones

\begin{tabular}{|l|l|l|}
\hline Types of Agricultural & Respondents & Percentage \\
\hline Quality seeds \& germination & 50 & 13.19 \\
\hline Fertilization information & 47 & 12.40 \\
\hline Pest control information & 43 & 11.35 \\
\hline Uncomplicated cultivation & 15 & 3.96 \\
\hline Preservation of crops and & 17 & 4.49 \\
\hline Poultry farm information & 35 & 9.23 \\
\hline Fishing information & 35 & 9.23 \\
\hline Dairy farming information & 20 & 5.28 \\
\hline Soil testing information & 15 & 3.96 \\
\hline Irrigation and water 40 & 10.55 \\
\hline Alternative cultivation & 25 & 6.60 \\
\hline Seasonal fruits, vegetables & 37 & 9.76 \\
\hline Total & 379 & 100 \\
\hline
\end{tabular}

Multiple responses $(\mathrm{N}=379)$

\subsection{Initiatives to Apply Knowledge in Agricultural Process after obtaining the Information}

If anyone is motivated by something to do anything, he/she tries to accomplish the tasks as of his/her strength. Table-9 demonstrates about the Initiatives of the farmers to apply in their cultivation process after obtaining the information. It reveals that majority number $45(64.28 \%)$ of respondents has taken the moderate initiatives to apply the techniques and strategies which he has learned through the mobile phone while $22.86 \%$ has taken the strong initiatives and $8.57 \%$ has taken the less strong initiatives with $4.29 \%$ has taken no initiatives to apply on their cultivation process.

Table-9: Extent of Initiatives to Apply Knowledge in Agricultural Process

\begin{tabular}{|l|l|l|}
\hline Extent of initiatives & Responden & Percentage \\
\hline Strong initiatives & 16 & 22.86 \\
\hline Moderately strong & 45 & 64.28 \\
\hline Less strong initiatives & 6 & 8.57 \\
\hline No Initiatives & 3 & 4.29 \\
\hline Total & 70 & 100.00 \\
\hline & & \\
\hline
\end{tabular}




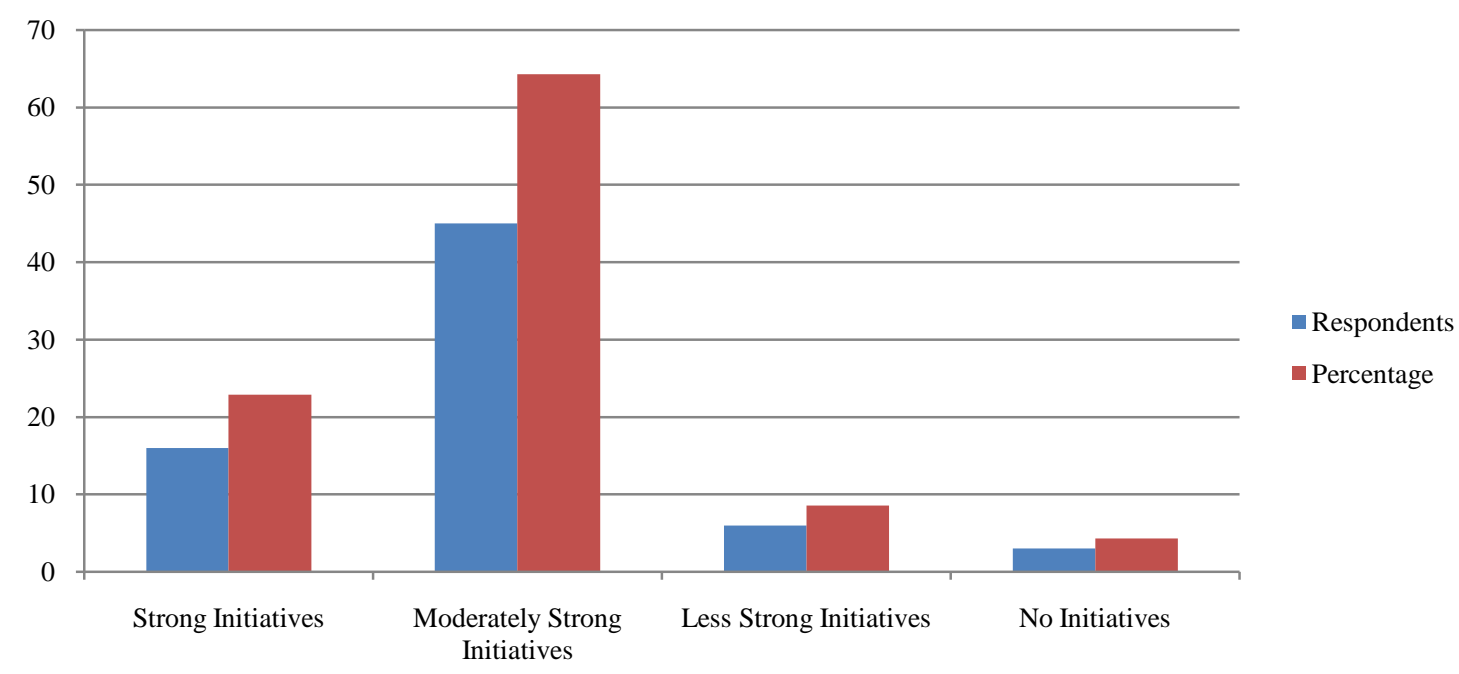

Chart-4: Extent of Initiatives to Apply Knowledge in Agricultural Process

\subsection{Result of Information Adopting in Agricultural}

\section{Production}

Table-10: Effect of Information Adopting in Agricultural Production

\begin{tabular}{|l|l|l|}
\hline Moderately high & 17 & 24.29 \\
\hline As of before & 5 & 7.14 \\
\hline Total & 70 & 100.00 \\
\hline & & \\
\hline
\end{tabular}

\section{Increment of Production Respondent Percentage}

\begin{tabular}{|l|l|l|}
\hline Very high & 9 & 12.86 \\
\hline High & 39 & 55.71 \\
\hline
\end{tabular}

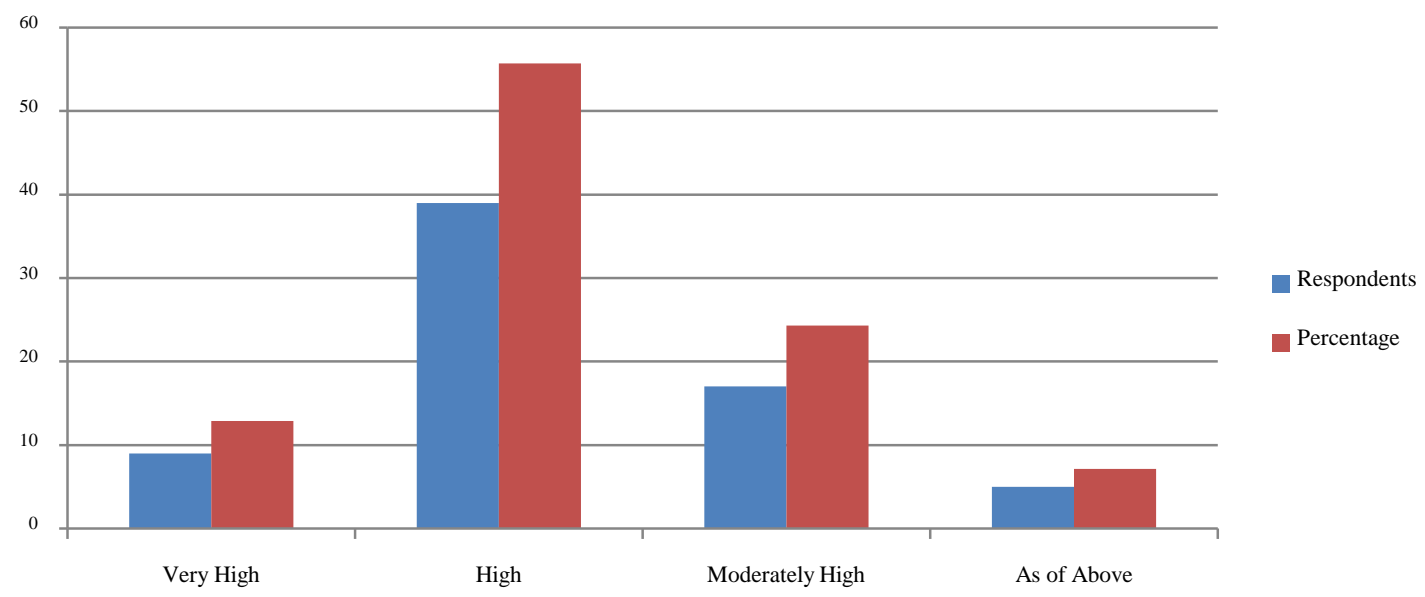

Chart-5: Effect of Information Adopting in Agricultural Production

\section{KEY FINDINGS}

$\checkmark \quad$ Majority number of respondent's age level is between (25-30) years. The largest proportion 18 (25.71\%) of the respondents have completed their primary education.

$\checkmark \quad$ It is noticed that the big number $38(54.28 \%)$ of respondents lead their live depending on the agriculture.

$\checkmark \quad$ Second majority number $18(25.71 \%)$ of respondents use mobile phone to get information every day.
Majority number $32(45.72 \%)$ of respondents uses Grameen phone to get the information.

$\checkmark \quad$ Majority number 50 (13.19\%) of respondents get the worth information regarding quality seeds from the mobile phones.

$\checkmark \quad$ It reveals that majority number 45 (64.28\%) of respondents has taken the moderate initiatives to apply the techniques and strategies which he has learned through mobile phones to their cultivable land. 
$\checkmark \quad$ A large portion of the farmer has been getting high production after utilizing the sought information from the mobile phones.

$\checkmark \quad$ Respondents were asked about the alternative sources of agricultural information where it is clear that most of the respondents get the agricultural information from Upazilla Agriculture Office.

\section{THEORETICAL FINDINGS}

The growth of mobile phone uses for disseminating the information towards the farmers for the development of agricultural sector in Bangladesh is obstacle over the years for so many reasons. Some of those reasons are been mentioned below:

\subsection{Education \& Computer Education}

Education, which is the backbone of a nation, is unfortunately seen as a corrupted sector in a developing country like in Bangladesh. Although the percentage of literacy is been increasing day by day in written but the matter-of-fact is that their education is limited only to put the signature. But to get the maximum benefit from the technological aspect the real education is been required and there is a huge lacking on it.

Computers have an important role in our modern life. The computer industry has just about taken over the world. We are using computer everywhere now a days. But it is critical because computer education in Bangladesh is not in good position. The lack of basic computer education is the barrier of developing a modern technology based society. Farmers in our country are still illiterate and their knowledge regarding computer are very poor. Most of them have hardly heard the name of computer.

\subsection{Language Proficiency, Native Language}

\section{Content}

Language plays an important role in influencing internet usage as well as mobile usage. Since the Internet is dominated by English language content, English speaking countries have a strategic advantage in popularization of the Internet use (Xiaoming, H. \& Kay, S.C. 2004). On the other hand, non-English speaking countries face enormous difficulty in tapping into the potential of the Internet as an information source (Ensafi, R., Zamiri, A. \& Kahani, M. 2007). The native language in Bangladesh is Bengali and hopefully the option of using Bengali language is available in using mobile phone but not in a greater extent.

\subsection{Lack of Public Awareness and Knowledge of ICT}

The public ICT literacy is still very low and almost nothing for the farmers. What concerned us the most is that ICT literacy among students and teachers are also low, especially those that live in the perimeters or remote areas. Here public awareness campaign through various media is absent (Khan,
S. 2009). The problem is that many computer literacy and information technology programs are still in the infant stage.

\subsection{Lack of Initiatives from the Government}

Although the vision of present government of Bangladesh is to make a digital Bangladesh by 2021, still enough initiatives are not been taken to make it actually happen. The way all modern facilities are available in city places are not been available in remote areas. The farmers who are living in the remote areas are still in the dark. They are deprived from all facilities what they should get. And because of that they are not been able to implement the latest technological aspect in their farming process.

\subsection{Lack of Financial Solvency}

The farmers of Bangladesh are not financially solvent enough. Most of them lead their lives from hand to mouth. So they are not been in a position to use the latest technology like mobile phone to get the latest information for their betterment.

\subsection{Mobile Operator's Ignorance}

Mobile operators have ignorance about e-agriculture that means they are not cordial enough to make the information available in a frequent manner and have a huge lacking in responding farmers query in a quick time. Even they are not been interested in introducing new applications which will go best for the rural farmers in getting their desired information. They also charge more for providing the information.

\subsection{Farmer's Ignorance:}

Farmers in our country are not much familiar with the use of mobile phone in an effective way. They mostly use the mobile phone for either making a call or receiving a call. So their ignorance is a major drawback in the technological advancement in our country.

\section{INSIGHTS AND RECOMMENDATIONS}

The governments in association with public sector should formulate clear policies that define the principles for their involvement in the development of agriculture sector in Bangladesh, by establishing and implementing national communication policy or ICT policy. And for this it will require collaboration between the agricultural and telecommunications sectors of government. Specifically, the policies should address issues related to i) quality and validation of agricultural content from the public sector, ii) accessibility and availability of all government data/information by the private sector and iii) accessibility, including the cost of information especially to the farmers. In this regard to make everything actually happen the government should take strong initiatives to make the farmers well educated with the computing knowledge. Otherwise everything will be spoiled before achieving anything.

Some specific recommendations are mentioned below: 


\subsection{Acceptability and Affordability}

The policy regarding the use of mobile phones should be accepted by all kinds of farmers. Farmers on low incomes should find the transactions affordable. Charges need to be designed around a greater volume of low value transactions, probably charging farmers free of cost in some cases.

\subsection{Ease of Use}

Mobile phone systems should be simple to use, fast and user friendly. Service should be standardized so that wherever the solution is used the farmer is familiar with the procedure followed. Farmers should have ready sources of advice, whether this is through call centers, through publicity or through physical presence.

\subsection{Functionality}

There is a continuing debate over the level of functionality that should be provided by the mobile operators. They should be always functional and should enrich their database with accurate, relevant and updated information.

Ideally, agricultural information services should be platform-independent, given that technology-specific services impose requirements on potential audiences and can greatly limit accessibility. All newer models of mobile phones support short message, or SMS-based, services in non-Latin character sets, which is very important in country like Bangladesh.

\section{PROPOSED ARCHITECTURE OF ICT THROUGH MOBILE PHONE FOR DISSEMINATING \\ REQUISITE \\ AGRICULTURAL INFORMATION FOR THE AGRICULTURAL DEVELOPMENT OF \\ BANGLADESH}

The general architecture of the proposed system is shown in Figure 8. The main component of the architecture is database server, which contains all the information that be provided. Now the way to access the information may be different based on the stakeholders. Farmers information system is a place connected with the central database and ready to provide information over mobile. A mobile server which is connected with the central database to provide information over mobile application. The application resides in the mobile server which eventually inherits information from the database server. A secured web-based system connected directly with the database server enables user to access the information over internet. An administrative end will be responsible for insert, delete, modify and update the information.

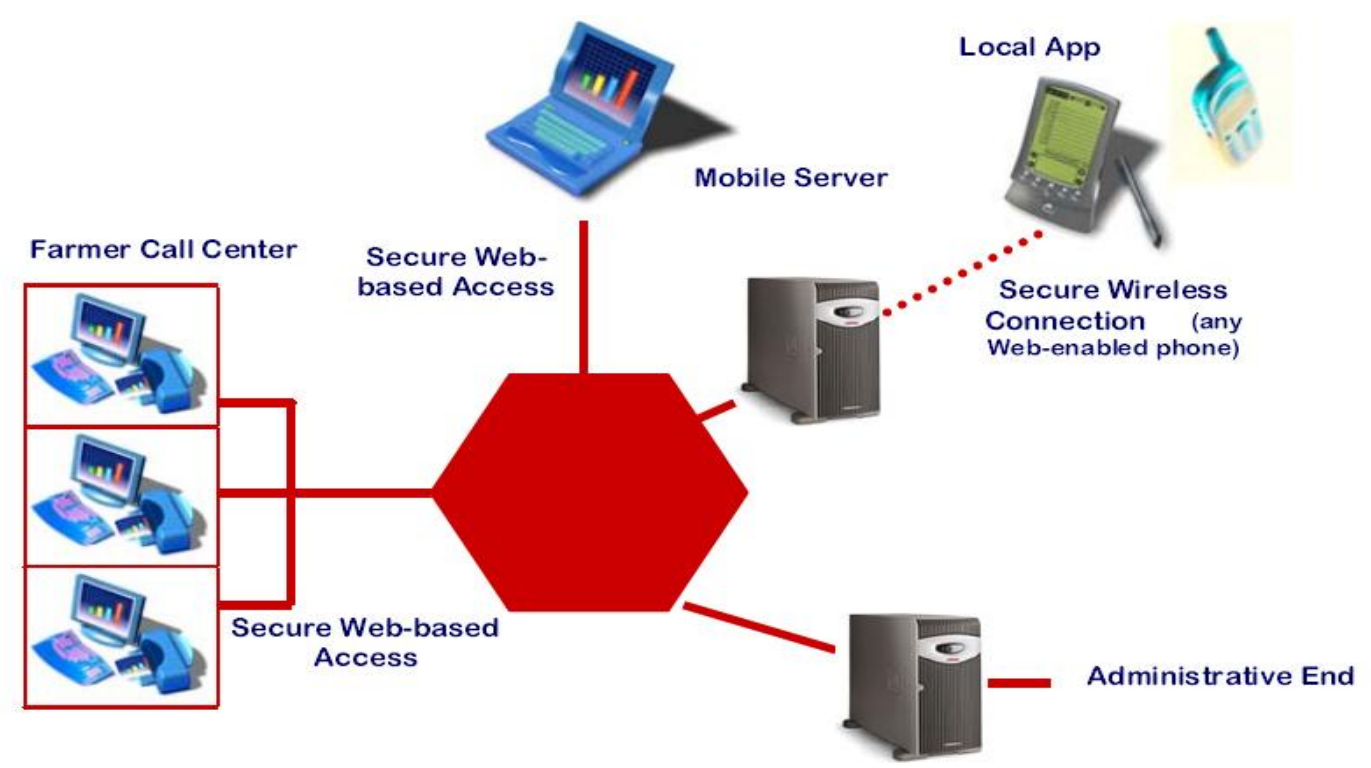

Fig-4: Proposed Architecture of ICT through mobile phone for Disseminating Requisite Agricultural Information for the Agricultural Development of Bangladesh

\section{CONCLUSION}

The concept of utilizing mobile phones to bridge information and knowledge gaps among farmers and rural service providers is based on two assumptions. The first is the near ubiquity of access and use of mobile phones. The second is that farmers (especially in developing economies) have specific information and knowledge needs that are currently only met partially, if at all. Agriculture and farmers are correlated. The development of the farmers will ensure the development of entire agriculture. The agricultural development will largely depends on how much farmers are aware of agriculture and in what extent they get the information. 
At present, the various mobile operators have been disseminating the effective agricultural information through different mobile applications. As a result, farmers are getting the valuable information on agriculture. But these are not sufficient. The mobile operators should be more conscious to put on air more agricultural information based application to create the awareness among the farmers so that they can put the best effort towards the development of the agriculture which will enhance the development of the country. As a result, Bangladesh will be ahead one more step.

\section{REFERENCES}

[1] Alam, M. (2007). E-Governance: Scope and Implementation Challenges in Bangladesh. International conference on Theory and practice of electronic governance. ICEGOV '07. Macao 2007.

[2] Alam, M., Ahmed, K. \& Islam, A. M. (2007). egovernance: challenges and opportunities. Theory and practice of electronic governance. Cayro, 2-4 December, 2008. ICEGOV'08.

[3] Backus, M. (2001). E-Governance and Developing Countries. [Online]. Available from: www.iicd.org/files/report3.doc

[4] Bangladesh ICT Policy Monitor Network. (2007). Available: http://bangladeshictpolicy. bytesforall.net

[5] Baten, M. A. \& Kamil, A. A. (2010). E-Banking of Economical Prospects in Bangladesh. Journal of Internet Banking and Commerce. [online]. 15(2).

[6] Beaumaster, S. (1999). Information Technology Implementation Issues: An Analysis. Dissertation submitted to the Faculty of the Virginia Polytechnic Institute and State University in partial fulfillment of the requirements for the degree of Doctor of Philosophy. Blacksburg, Virginia: Virginia Polytechnic Institute and State University.

[7] Bose, S. \& Rashel, M. R. (2007). Implementing E-Governance Using OECD Model(Modified) and Gartner Model (Modified) Upon Agriculture of Bangladesh. International conference on Computer and informsation technology. Dhaka, 27-29 Dec. 2007. Dhaka: iccit . p $1-5$

[8] Brooke, C. (2002). Critical Perspectives on Information Systems: An Impression of the Research Landscape. Journal of Information Technology, p 271-283.

[9] Burr, W. (1996). "Wie Informations technik Die Bank organisation Verändern Könnte," In Lustsik, O (2004), Can E-Banking Services Be Profitable?. Tartu University Press, Estonia.

[10] Chang, YT (2003). Dynamics of banking technology adoption: an application to internet banking. Department of Economics, Workshop Presentation, University of Warwick, Coventry, UK

[11] Campbell, D.T., Stanley, J.C. (1966). Experimental and Quasi-Experimental Designs for Research. Skokie, Il: Rand McNally.
[12] Digital Bangladesh. Revitalizing key service sector. [Online]. Available from: http://www. digitalbangladesh.gov.bd/documents/Education_chap ter.pdf

[13] Ensafi, R. Zamiri, A. \& Kahani, M. (2007). ICT Challenges in education: Reflections from a developing country: Iran, with reference to the statistics from computer science students. 2nd International Conference on Virtual Learning. Romania, October 26th - 28th, 2007.Romania: ICVL. p 1-5

[14] Farooq, S. et al (2004). Study of E-government in Bangladesh. [Online].

[15] FAO. (2002). The role of agriculture in the development of least-developed countries and their integration into the world economy. [Online].

[16] FAO(2005). e-Agriculture: A Definition and Profile of its Application, Bridging The Rural Digital Divide [Online]. Available from: http://www.fao.org/rdd/doc/e-agriculture\%2014-10051.pdf

[17] Fung, Z. (2002). E-Government in Digital Era: Concept, Practice, and Development. International Journal of The Computer, The Internet and Management, Vol. 10, No.2, 2002, p 1-22.

[18] Furst K, Lang W, Nolle D (2000). Who offers internet banking? Special Studies on Technology and Banking, Q. J. [Online]. Available from: www.occ.treas.gov/special7-6.pdf.

[19] Gonçalves, N. P. \& Sapateiro, C. M. (2008). "Aspects for Information Systems Implementation: challenges and impacts. A higher education institution experience". Revista de Estudos Politécnicos Polytechnical Studies Review 2008. Vol VI, no 9.

[20] Hasan,A. Baten,M. Kamil,A. Parveen,S (2010). Adoption of e-banking in Bangladesh: An exploratory study. African Journal of Business Management Vol. 4(13), pp. 2718-2727

[21] Heeks, R. (2003). Most e-Government -for Development Projects Fail: How can Risks be Reduced?" iGovernment Working Paper Series, paper no. 14 .

[22] Just, D. \& Zilberman,D. Information system in agriculture [Online].

[23] Khan, S. (2009). ICT and Education in Bangladesh. [Online]. 05 December 2009.

[24] Lind Ann, (2005). Successful knowledge creation in virtual communities-Influencing factors and driving forces. Master's thesis in informatics at the school of business and informatics 2005: XX.

[25] Mohamed, E. \& Tahon, E. Electronic Government (e-government) Concept and definitions. Cairo University. [Online]. 


\section{BIOGRAPHIES}

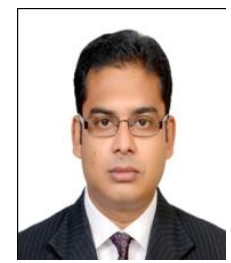

Md. Mahedi Hasan received Master of Business Administration (M.B.A.) Major in MIS, from Sikkim Manipal University Of Health Medical \& Technological Sciences, India and B.Sc (Hons) in Computer Science from Bangalore University, India, Presently Working as an Assistant Professor, Department of Business Administration, Prime University, Dhaka, Bangladesh. His areas of interest include E-commerce, E-payment, Digital Image, and MIS. PH: 008801856413543 ,

E-mail: mismanipal245@gmail.com 